\title{
Study on Post Groups of Logistics Management and Modern Apprentice Professional Ability in Higher Vocational Education*
}

\author{
Shijun Yuan \\ Hunan Modern Logistics College \\ Changsha, China 410131
}

\author{
Xiangyang Liao** \\ Hunan Modern Logistics College \\ Changsha, China 410131 \\ **Corresponding Author
}

\begin{abstract}
Based on the investigation and analysis of the professional post groups of the competent departments, employers and graduates in the logistics industry, this paper analyzes the general professional ability of the typical post groups, which provides a reference for the talent training of the logistics management major in higher vocational colleges.
\end{abstract}

Keywords - higher vocational education; logistics management major; post group; professional ability

\section{INTRODUCTION}

Vocational ability of students cannot be equal to employment ability. Vocational ability of graduates majoring in logistics management should be reflected in their ability to integrate the theoretical knowledge, operation skills and attitude towards work they have learned in specific employment units, and to transfer and integrate their own abilities and qualities to complete specific professional tasks. Therefore, the cultivation of their professional ability must be based on the professional ability required by the jobs of the students. Through the investigation and analysis of the requirements of the logistics industry, the post group of enterprises and their posts on the ability and quality of talents, this paper analyzes the corresponding professional ability of the post group of the logistics management major in higher vocational education, so as to lay the foundation for the cultivation of their professional ability.

\section{SURVEY ON POST GROUPS OF LOGISTICS}

\section{MANAGEMENT Major IN Higher Vocational EdUCATION}

Through interview, observation, network survey and questionnaire survey, the logistics management teaching team of our college conducted a special survey on the demand of the competent logistics departments and employers such as Hunan Federation of Logistics and Purchasing, Hunan Development and Reform Commission, Human Economic and Information Technology Commission, well-known production and manufacturing enterprises in Hunan, commerce and trade

*Fund: The project in "the 13th Five-Year Plan for Education Science in Hunan Province in 2018 - Phased Results based on Research on "Doublesubject and Dual-identity" Apprentice Collaborative Management Mechanism (XJK18BZY042) in School-enterprise Cooperative Secondary College. circulation enterprises, logistics enterprises, logistics parks, for students of logistics management major in higher vocational colleges. Meanwhile, the follow-up survey was also conducted on graduates of our college. Through investigation, it is able to deeply know the development trend of logistics industry in China and our province, the development trend of different regional industries, the demand of enterprise logistics outsourcing, the number of personnel employed by logistics departments and logistics enterprises, and their personnel requirement, focus on the development demand of various industries for the development of regional economy in Hunan Province, and investigate and understand the status of logistics practitioners, including post setting and personnel quality demand and loss rate. Through the follow-up survey of graduates, it is able to grasp the technical skills, literacy and employment of students, so as to optimize the structures of major and professional groups, improve the personnel training mode and curriculum system, perfect the practical teaching system and give full play to the function of training base, strengthen the construction of teaching resources, improve the level of teachers' team, and lay the foundation and provide the basis for the cultivation of students' professional ability.

III. AnAlysis on InVEStigation Results of Post GROUPS FOR LOGISTICS MANAGEMENT MAJOR IN HigHER VOCATIONAL EDUCATION

\section{A. Overview of Enterprises and Post Groups for Logistics Management Major in Higher Vocational Education}

Third-party logistics enterprises: specifically responsible for middle-level management of warehousing, distribution, transportation and other logistics activities in warehousing enterprises, transportation enterprises and comprehensive logistics enterprises (such as logistics park).

Production enterprise: specifically responsible for management of purchasing, production supply logistics, semifinished goods logistics and finished goods sales logistics in the logistics department of the production enterprise or the separated logistics company.

Commercial circulation enterprises: specifically responsible for the purchase, distribution, recycling and other 
and implement plans and schemes for maintenance and use of operation equipment and facilities; fifth, they are able to make operation management decisions based on daily business data of warehousing and distribution; sixth, they are able to effectively implement construction documents and information processing management, operation safety management, equipment and facilities maintenance and operation site management.

The specific posts included in the transportation management post group include the cargo collection and transportation post, dispatching post, freight forwarding post, transportation supervisor post, transportation business development post, safety supervision post, transportation information management post, etc. The general professional abilities of the post group: first, they are able to expand transportation market and communicate with customers; second, they are able to make personalized transportation plans and schemes according to customers' needs; third, they have the ability to calculate the cost and benefit of specific cargo transportation activities; fourth, they have the ability to analyze the risk of specific transportation activities and formulate risk control measures; fifth, they have the ability to make risk control measures according to daily transportation business related data analysis, transportation decision-making; sixth, they can effectively carry out the incentive and training of personnel, equipment management, safety management, etc.

Second one is storage and distribution business management ability. This includes the ability to be familiar with the logistics business process, be familiar with the acceptance, storage, inventory, delivery, picking, loading and distribution of goods.

Third one is transportation business ability. Transportation business is not a single simple process of goods collection, distribution and shipment. In the process of multimodal transport, there are still big loopholes in quotation, bidding, scheme planning and design, network layout and management.

In addition, the enterprise believes that graduates also need to have the following qualities, such as taking delight in the post, being able to adapt to the work quickly, and being able to bear the work pressure.

\section{ANALYSIS OF TyPICAL POSTS OF POST GROUPS AND GENERAL PROFESSIONAL ABILITY FOR LOGISTICS MANAGEMENT MAJOR IN HIGHER VOCATIONAL EDUCATION}

The specific positions included in the storage and distribution management position group include receiving operation and management position, storage operation and management position, circulation processing operation and management position, delivery operation and management position, cargo loading operation and management position, information management position. The general professional abilities of storage and distribution: first, students should able to manage the storage and distribution operation plan, and have the ability of resource allocation and integration; second, they are able to carry out process optimization, operation guidance and exception handling for warehousing and distribution; third, they are able to carry out performance assessment and cost-benefit analysis for each link of warehousing and distribution; fourth, they are able to organize
V. ANALYSIS ON THE CURRENT SitUATION OF THE

TRAINING OF MODERN APPRENTICE'S PROFESSIONAL ABILITY FOR LOGISTICS MANAGEMENT IN HIGHER VOCATIONAL EDUCATION

\section{A. Misunderstandings About the Identity of Logistics Skills with Logistics Professional Ability}

At present, some enterprises and schools do not fully grasp the connotation of logistics professional ability, and onesidedly think that training vocational logistics management graduates' professional ability is to train their logistics operation skills, focusing on the training of students' logistics operation of a certain professional skills. Facing the increasingly developing logistics industry, it is not only required that the graduates of higher vocational logistics management who go to work directly not only have the operation skills of a specific post, but also have the knowledge ability structure and innovation ability corresponding to the post or operation skills. According to the survey of relevant employers in the logistics industry, enterprises pay more attention to the comprehensive quality and ability in the recruitment process of middle-level logistics operation and management talents, not just the practical operation ability, because the practical operation ability of specific posts can be achieved by short-term post training, while the cultivation of comprehensive professional ability is a long-term process.

\section{B. The Lack of "Double-qualified" Teachers}

In order to cultivate high skilled logistics talents, teachers with innovative consciousness and ability and strong practical ability are indispensable. At present, a considerable part of higher vocational colleges recognize "double-qualified" 
teachers as long as they have teacher qualification certificate (lecturer and above) and professional and technical professional qualification certificate (such as logistics teacher) in logistics industries. They can enjoy "double-qualified" teacher's treatment. However, there are few teachers who have rich practical experience in enterprise logistics operation and management, so it has a certain impact on the vocational ability training of logistics management graduates.

\section{Undeveloped Practical Training Function of Productive Training Base}

In order to achieve the goal of cultivating graduates' professional ability, vocational colleges have basically cooperated with enterprises to build productive training bases. However, the productive training bases are often only used to make materials and publicity for the school. Only a few logistics productive training bases are really used for teaching and practical teaching. Students are more likely to attend relevant training in the classroom, theory teaching and related practice training in the training room of the school. The practice teaching in the production training base outside the school which is really oriented to the society and the whole post is too lacking to give full play to the role of students' vocational ability training.

\section{MEASURES For TRAINING MODERN APPRENTICE'S PROFESSIONAL ABILITY FOR LOGISTICS MANAGEMENT IN HIGHER VOCATIONAL EDUCATION}

\section{A. To Clearly Know the Post Capacity Demand and Adjust the Talent Training Mode}

The logistics management higher vocational colleges should go deep into the logistics industry, logistics enterprises, and industrial and commercial logistics departments every year in order to carry out the research on the logistics posts and professional ability requirements of enterprises and the demand for talents. Guided by the market demand of the logistics industry and logistics enterprises, and based on the professional requirements and post ability of the logisticsrelated posts of the logistics industry, enterprises and other employers, it is able to clearly know the related positions ducked by higher vocational colleges, actively create conditions, adjust the school-running orientation and talent training mode of the college in real time, reconstruct the curriculum system according to the professional ability required by the positions of the enterprise, and do a good job in the connection of "secondary vocational, higher vocational school and college" talent training, so as to meet the needs of the sustainable development of the position ability of the students.

\section{B. To Strengthen the Establishment of "Double-qualified" Teacher}

Around the training of vocational logistics management graduates' professional ability, it is suggested to build a professional teaching team which is composed of industry enterprise experts and school teachers, with professional leaders as the core, backbone teachers as the guide, "doublequalified" quality teachers as the main body, and school- enterprise mutual engagement. It is necessary to set up a professional tutor system, give full play to the role of backbone teachers, implement pair assistance and one-to-one training, and promote the rapid growth of young teachers and the overall improvement of the quality of teachers. By encouraging teachers to go to enterprises, experts to enter the classroom, professional backbones to visit foreign countries and other measures, the overall level of higher vocational teachers can be improved, and the proportion of doublequalified teachers can reach $100 \%$.

\section{To Deepen School-Enterprise Cooperation and Improve Practical Teaching Conditions}

Higher vocational colleges should further emphasize the win-win cooperation with "leading enterprises in the logistics industry", and let both sides of the school and enterprise becomes the community of interests. According to their professional construction planning, talent training objectives, post professional ability needs, it is necessary to build a productive training base to meet the on-the-job internship and comprehensive training of logistics management graduates, and ensure that the training facilities and equipment in the training base reach the advanced industrial level in China, and all posts of the logistics management major face corresponding internship posts to realize the integration of production, education and research and development. Professional teachers can exchange posts with on-site experts of the enterprise. The enterprise can provide job opportunities for college graduates, while enterprise employees can receive vocational training provided by colleges. In this way, it is able to realize the integration of talent resource development and the integration of campus culture and enterprise culture.

\section{CONCLUSION}

According to the post group corresponding to the modern apprentice of logistics management in higher vocational education, this paper analyzes the difference among the post groups corresponding to the logistics management major in secondary and higher vocational education and undergraduate education, and creates targeted conditions. In addition, it can effectively achieve the training of their professional ability through innovative personnel training mode, optimization of curriculum system and practical teaching conditions, and improvement of the quality of teachers.

\section{REFERENCES}

[1] Tang Xiangling. Research on Vocational Ability Training of Vocational College Students. Master's Degree Thesis of Wuhan University of Technology, 2006. (in Chinese)

[2] Yuan Shijun, Hu Yuanqing. Comparative Analysis of Talent Training Objectives of Logistics Management in "Secondary and Higher Vocational Schools and Colleges. Science and Technology Outlook, No. 22, 2014. (in Chinese) 